\title{
Partial Replacement of Fishmeal with Marine Algae Turbinaria ornata and Gracilaria corticata for Sustainable Culture of the Freshwater Prawn Macrobrachium rosenbergii
}

\author{
Gopalan Rajkumar ${ }^{1}$, Periyakali Saravana Bhavan ${ }^{1}$, Veeran Srinivasan ${ }^{2}$, \\ Rajendran Udayasuriyan ${ }^{1}$, Madhayan Karthik ${ }^{1}$, Thangavelu Satgurunathan ${ }^{1}$ \\ ${ }^{1}$ Department of Zoology, Bharathiar University, Coimbatore, Tamil Nadu, India \\ ${ }^{2}$ Department of Animal Science, Bharathidasan University, Tiruchirappalli, Tamil Nadu, India
}

\begin{abstract}
This study was conducted to assess whether edible seaweeds, Turbinaria ornata and Gracilaria corticata can be partially replaced the fishmeal to promote the growth of the freshwater prawn, Macrobrachium rosenbergii post larvae (PL). Control was prepared with fishmeal, groundnut oilcake and soy bean meal as protein sources, wheat bran as carbohydrate source, sun flavor oil as lipid source, and topica flour and egg albumin as binding agents. Isonitric experimental diets were prepared by $25 \%$ and $50 \%$ replacements of the fish meal with T. ornata and G. corticata separately. These feeds were fed to M. rosenbergii PL for 90 days. Among these $25 \%$ fishmeal replaced diets with $T$. ornata and G. corticata produced significantly better survival and growth when compared with control. Among the fishmeal replacement seaweeds, G. carticata was performed better than that of T. ornata. The 50\% replacements of the fishmeal showed poor performance when compared with control. In the $25 \%$ fishmeal replaced categories, the muscle total protein, amino acid, carbohydrate, lipid and ash, profiles of proteins, amino acids and fatty acids, and activities of digestive enzymes, such as protease, amylase and lipase were elevated due to the influence of T. ornata and G. corticata. Thus, $25 \%$ replacement of the fishmeal with these algae is recommended for sustainable production of M. rosenbergii.
\end{abstract}

Keywords: Turbinaria ornata, Gracilaria corticata, Macrobrachium rosenbergii, Survival, Growth, Protein, Amino acid, Fatty acid, Digestive enzymes.

\section{INTRODUCTION}

The giant freshwater prawn, Macrobrachium rosenbergii, 'Scampi' is commercially cultured in India, China, Taiwan, Bangladesh, Vietnam, Thailand and in South America (New and Nair, 2012). It is one of the most important cultured crustaceans being farmed to promote rural livelihood and contributes to global food security. It represents a good source of protein, essential amino acids and polyunsaturated fatty acids, and very low in fat. Thus, it is being used as a delicious healthy choice of food for human consumption. However, its culture is relied upon availability of quality seed and feed. Live feeds can be given only to larval and early post-larval staged prawns. In the late post-larval, juvenile and grow-out stage, aqua-farmers need to procure artificial feeds, which constitute a major operational cost. Since the fishmeal is a depleting high-cost principal natural resource, the small farmers find it difficult to afford. According to Hardy (2001) the world fish meal production has been nearly constant, averaging about $62,00,000 \mathrm{mt}$ over the past 15 years, and since demand for fish meal is growing, fish meal prices are expected to continue to increase. The formulation of feeds using locally available low cost agricultural, animal husbandry and industrial by-products have crucial role in aquaculture industry (Mitra et al., 2005; Langer, 2011). Literature shown that the fishmeal can effectively be replaced by alternative protein sources such as soybean protein and poultry by-products (Kaushik et al., 1995; Goda et al., 2007; Hernandez et al., 2010). In recent years, marine resources have attracted attention in the search for bioactive compounds to develop new drugs and healthy foods. It could not be completely replaced with any other material. However, only partial replacement can be possible with some plant/animal resources and their byproducts. Therefore, searching for alternate finite compound source for formulating a well-balanced diet and their adequate feeding are the most important for successful aquaculture of $M$. rosenbergii. 
Seaweeds have been considered as potential sources for antibiotics, cancer therapeutics, hypocholesterolemic and antihelminthic substances (Salvador et al., 2007; Manilal et al., 2009; Manivannan et al., 2011). Marine macro algae are very important and commercially valuable resources for food, fodder, soil conditioners and pharmaceuticals (Yang et al., 2006). The brown algae are most commonly utilized for additive preparations or as a feed in animal nutrition (Indegaard and Minsaas, 1991). The proximate composition of brown algae have been reported to vary from species to species, they are ranging from $9-16 \%$ of protein, $14-25 \%$ of carbohydrate, $1.5-4 \%$ of lipids (Murugaiyan et al., 2012; Parthiban et al., 2013). Thus, the present study was dealt with partial replacement of fishmeal by edible marine macro algae, Turbinaria ornata (brown) and Gracilaria corticata (red) which are available aplenty in coastal regions of Indian subcontinent. First their proximate biochemical compositions including fatty acid profile were assessed. And then their potential have been evaluated by studying effects on the survival, growth, nutritional indices, concentrations of basic biochemical constituents (total protein, carbohydrate, lipid and amino acid), profiles of protein and amino acids and activities of digestive enzymes (protease, amylase and lipase) on the late aged post-larvae of $M$. rosenbergii.

\section{Materials ANd Methods}

\subsection{Collection and identification of marine algae}

The marine algae (T. ornata and G. corticata) were collected from the intertidal region of Mandapam coast (Lat. $9^{\circ} 17^{\prime} \mathrm{N}$; Lon. $79^{\circ} 19^{\prime} \mathrm{E}$ ) of Gulf of Mannar, south-east coast of Tamil Nadu, India. The macro alga species was identified based on its morphology by using identification manual of "Economically Important Seaweeds" (Kaliaperumal et al., 1995) published by Central Marine Fisheries Research Institute (ICAR), Kochi, India. Finally, the species (BSI/SRC/23/2015/Tech./975; BSI/SRC/23/2015/Tech./976) were authenticated by Botanical Survey of India (BSI), Coimbatore, India.

\subsection{Proximate composition and fatty acid profile of marine algae}

The collected samples were cleaned well with seawater to remove all the extraneous matter such as epiphytes, sand particles and necrotic parts, and brought to the laboratory in plastic bags. The samples were then thoroughly washed with freshwater, blotted, spread out and dried at room temperature for 2 weeks. Shade dried samples were ground to fine powder and stored in sterilized containers for further usage. The powdered algae were subjected to proximate composition analysis by adopting the methodology of Castell and Tiews (1980) as given in AOAC (1995) and the results are presented in table 1 , which contain, $14.40-19.30 \%$ of crude protein, $17.49-25.14 \%$ of crude fibre and $1.67-$ $1.80 \%$ of etheric extract, $25.11-29.90 \%$ of total ash, $9.40-10.40 \%$ of moisture, $26.26-28.34 \%$ of nitrogen free extract, $1.23-2.12 \%$ of sand and silica, $0.25-0.46 \%$ of calcium, $1.54-1.75 \%$ of phosphorus, $1.11-1.34 \%$ of salt and $3546-3781 \mathrm{kcal} / \mathrm{kg}$ of gross energy. The powdered algal samples were also subjected to analysis of fatty acid profile by adopting Gas Chromatographic method of Nichols et al. (1993) and the results are given in table 2, which contain fatty acids profile of 50.27$53.56 \%$ of SFA, $25.11-29.90 \%$ MUFA (olecic acid), and PUFA \% of $10.55-11.34$ and $1.65-$ 1.98 for linoleic and linolenic acids respectively.

Table 1: Proximate biochemical composition (\%) of marine algae

\begin{tabular}{|l|l|l|}
\hline Composition & T. ornata & G. corticata \\
\hline Crude protein & $14.40 \pm 1.20$ & $19.30 \pm 1.20$ \\
\hline Crude fibre & $17.49 \pm 1.87$ & $25.14 \pm 1.87$ \\
\hline Etheric extract & $1.67 \pm 0.34$ & $1.80 \pm 0.34$ \\
\hline Total ash & $25.11 \pm 2.30$ & $29.90 \pm 2.30$ \\
\hline Moisture & $10.40 \pm 0.57$ & $9.26 \pm 0.57$ \\
\hline Nitrogen free extract & $26.14 \pm 6.28$ & $28.34 \pm 6.28$ \\
\hline Sand and silica & $1.23 \pm 0.23$ & $2.12 \pm 0.23$ \\
\hline Calcium & $0.25 \pm 0.03$ & $0.46 \pm 0.03$ \\
\hline Phosphorus & $1.54 \pm 0.31$ & $1.75 \pm 0.31$ \\
\hline Salt & $1.34 \pm 0.24$ & $1.11 \pm 0.24$ \\
\hline Gross energy $(\mathrm{kcal} / \mathrm{kg})$ & $3546 \pm 88.00$ & $3781 \pm 88.00$ \\
\hline
\end{tabular}

Each value is mean \pm standard deviation of three individual observations. 
Partial Replacement of Fishmeal with Marine Algae Turbinaria ornata and Gracilaria corticata for Sustainable Culture of the Freshwater Prawn Macrobrachium rosenbergii

Table 2: Profiles of fatty acids (\%) of marine algae

\begin{tabular}{|l|l|l|l|}
\hline \multicolumn{2}{|l|}{ Fatty acids } & T. ornata & G. corticata \\
\hline \multirow{4}{*}{ SFA } & Myristic acid (C14:0) & $6.54 \pm 1.10$ & $6.79 \pm 1.23$ \\
\cline { 2 - 4 } & Palmitic acid (C16:0) & $34.98 \pm 2.87$ & $36.62 \pm 2.93$ \\
\cline { 2 - 4 } & Stearic acid (C18:0) & $4.18 \pm 0.93$ & $4.77 \pm 1.05$ \\
\cline { 2 - 4 } & Arachidic acid (C20:0) & $0.76 \pm 0.18$ & $1.15 \pm 0.26$ \\
\cline { 2 - 4 } & Behenic acid (22:0) & $3.87 \pm 0.63$ & $4.23 \pm 0.84$ \\
\hline MUFA & Olecic acid (C18:1) & $25.11 \pm 3.57$ & $26.32 \pm 3.87$ \\
\hline PUFA & Linoleic acid (C18:2n-6) & $10.55 \pm 1.71$ & $11.34 \pm 1.89$ \\
\cline { 2 - 4 } & Linolenic acid (C18:3n-3) & $1.65 \pm 0.38$ & $93.20 \pm 12.56$ \\
\hline SFA & & $87.64 \pm 11.37$ & $53.56 \pm 6.31$ \\
\hline$\sum$ SFA & & $50.33 \pm 5.71$ & $13.32 \pm 2.38$ \\
\hline$\sum$ MUFA & & $25.11 \pm 3.57$ & $1.98 \pm 0.49$ \\
\hline$\sum$ PUFA & & $12.20 \pm 2.09$ & $1.34 \pm 1.89$ \\
\hline n-3 & & $1.65 \pm 0.38$ & \\
\hline n-6 & & $10.55 \pm 1.71$ & \\
\hline
\end{tabular}

Each value is mean \pm standard deviation of three individual observations.

FA, fatty acids; SFA, saturated fatty acids; MUFA, mono unsaturated fatty acids; PUFA, poly unsaturated fatty acids.

\subsection{Experimental animal}

The post larvae (PL-30) of the freshwater prawn, M. rosenbergii were procured from ADAK Hatchery, Odayam, Varkala, Thiruvananthapuram, Kerala, India. They were transported to the laboratory in polythene bags filled with oxygenated water. The prawns were acclimatized to ambient laboratory conditions for 2 weeks in large cement tank $(1000$ L) with ground water (temperature, $28 \pm 2.0 ; \mathrm{pH}, 7.0 \pm 0.20$; total dissolved solids, $0.96 \pm 0.07 \mathrm{~g} \mathrm{~L}^{-1}$; dissolved oxygen, $7.10 \pm 0.30 \mathrm{mg} \mathrm{L}^{-1}$; BOD, 32.0 $\pm 3.00 \mathrm{mg} \mathrm{L}^{-1}$; COD, $136.0 \pm 11.00 \mathrm{mg} \mathrm{L}^{-1}$; ammonia, $0.030 \pm 0.007 \mathrm{mg} \mathrm{L}^{-1}$ ), APHA (2005). During acclimatization the prawns were fed with boiled egg albumin and artificially formulate feed (our laboratory prepared feed). More than 50\% of tank water was routinely changed every day in order to maintain a healthy environment and aeration was also provided. The unfed feed, faeces, moult and dead prawns if any were removed by siphoning without disturbing the prawns.

\subsection{Preparation of experimental diets}

The following branded feed basal ingredients (BI) were taken to formulate the experimental feed. The fish meal, groundnut oilcake and soybean meal as protein sources, wheat bran as carbohydrate source, sunflower oil as lipid source, and tapioca flour and egg albumin were used as binding agents. The fish meal, groundnut oilcake, soybean meal, wheat bran and tapioca flour were thoroughly mixed, a dough was prepared with sterilized water, then it was steam cooked and cooled at room temperature. Then the Sunflower oil and egg albumin were added to the dough and mixed well. T. ornata and G. corticata powders were incorporated separately with the dough of BI at two different concentrations, $25 \%$ and $50 \%$ by replacing the right quantity of fishmeal, and in order to prepare iso-nitric diets, the protein level was maintained by adjusting the groundnut oilcake and soybean meal (Table 3). Sterilized water was adequately added for maintaining the dough in moist and paste form. Then it was pelletized in a manual pelletizer (Kolkata, India) fixed with $3 \mathrm{~mm}$ diameter mesh. The pellets were dried in a thermostatic oven (M/s Modern Industrial, Mumbai, India) at $40^{\circ} \mathrm{C}$ until they reached constant weight and stored in airtight jars at room temperature. The pelletized feeds were subjected to proximate composition analyses (AOAC, 1995) and the results are also presented in table 3 . The total organic matters present in the basal diet (control) and experimental diets contained $42.26-42.55 \%$ of crude protein, $4.20-4.39 \%$ of crude fat, $1.16-1.24 \%$ of crude fibre, $7.50-7.63 \%$ of total ash, $8.89-8.98$ $\%$ of moisture, $35.30-35.89 \%$ of total carbohydrate and $4224-4347(\mathrm{kcal} / \mathrm{kg})$ gross energy. It is important to mention here that freshwater prawn requires 30-40\% crude protein, $25-35 \%$ carbohydrate and 3-7\% lipid (Swamy, 1995; Mitra, 2005). Therefore, the formulated feeds satisfied the prescribed proximate composition. 
Table 3: Ingredients used to formulate iso-nitric diets, and proximate composition ( $\mathrm{g}$ ) of marine algae

\begin{tabular}{|l|c|c|c|c|c|}
\hline \multirow{2}{*}{ Basal ingredients (BI) } & \multirow{2}{*}{ Control } & \multicolumn{3}{|c|}{ Partially fishmeal replaced diets } \\
\cline { 3 - 6 } & & \multicolumn{2}{|c|}{ T. ornata } & \multicolumn{2}{c|}{ G. corticata } \\
\cline { 3 - 6 } & 25.00 & $25 \%$ & $50 \%$ & $25 \%$ & $50 \%$ \\
\hline Fish meal & 25.00 & 29.00 & 34.00 & 29.00 & 34.00 \\
\hline Groundnut oil cake & 25.00 & 29.00 & 34.00 & 29.00 & 34.00 \\
\hline Soybean meal & 10.00 & 11.00 & 12.00 & 11.00 & 12.00 \\
\hline Wheat bran & 07.00 & 07.70 & 08.40 & 07.70 & 08.40 \\
\hline Egg albumin & 05.00 & 05.50 & 06.00 & 05.50 & 06.00 \\
\hline Tapioca flour & 02.00 & 02.20 & 02.40 & 02.20 & 02.40 \\
\hline Sunflower oil & 01.00 & 01.10 & 01.20 & 01.10 & 01.20 \\
\hline Vitamin mix* & & 06.25 & 12.50 & 06.25 & 12.50 \\
\hline T. ornata / G. corticata & 100.00 & 110.50 & 123.00 & 110.50 & 123.00 \\
\hline Total & & & & & 4.50 \\
\hline Proximate \\
composition of diets
\end{tabular}

*. Each capsule contains, Total mg = $438.5 \mathrm{mg}$; Thiamine Mononitrate IP, $10 \mathrm{mg}$; Riboflavin IP, $10 \mathrm{mg}$; Pyridoxine Hydrochloride IP, $3 \mathrm{mg}$; Vitamin B12 (as tablets 1:100) IP, 15 mcg; Niacinamide IP, $100 \mathrm{mg}$; Calcium pantothenate IP, $50 \mathrm{mg}$; Folic acid IP, $1.5 \mathrm{mg}$; Biotin USP, $100 \mathrm{mcg}$; Ascorbic acid IP, $150 \mathrm{mg}$ manufactured by Pfizer.

BI, basal ingredients.

\subsection{Feeding trials}

M. rosenbergii PL (PL-45; $2.02 \pm 0.02 \mathrm{~cm}$ length; $0.12 \pm 0.01 \mathrm{~g}$ weight) was starved for $24 \mathrm{~h}$ before commencing the feeding trial. Five groups, each with $30 \mathrm{PL}$ were maintained in $30 \mathrm{~L}$ plastic tanks under a triplicate experimental set-up. One group served as control and fed with feed formulated by without incorporation of $T$. ornata and G. corticata, and the other four groups were fed with experimental feeds prepared by incorporation of T. ornata (at 25\% and 50\%) and G. corticata (at $25 \%$ and 50\%) respectively by replacing the right quantity of the fishmeal. The feed was allocated to the prawns for two times a day $(7: 00 \mathrm{am}$ and 7:00 pm) at 10\% of body weight. The experiment was extended for a period of 90 days, by this time it reached juvenile stage. The unfed feed, feces and moult (if any) were collected on daily basis by siphoning method causing minimum disturbance to the prawns during renewal of water. For morphometric and nutritional analysis 10 prawns from each group were randomly measured and the mean was considered as a single value (mean of 10 individual measurements $=$ one observation), and three such measurements were made to fulfill the triplicate analysis.

\subsection{Evaluations of growth and nutritional indices}

After the 90 days feeding trial, the growth parameters, such as survival rate (SR), length gain (LG), weight gain (WG), specific growth rate (SGR) and food conversion rate (FCR) were determined (Tekinay and Davies, 2001).

$$
\begin{gathered}
\text { Survival rate, } \mathrm{SR}(\%)=\frac{\text { Total No. of live prawns }}{\text { Total No. of prawns introduced initially }} \mathrm{X} 100 \\
\text { Length gain, } \mathrm{LG}(\mathrm{cm})=\text { Final length }(\mathrm{cm})-\text { Initial length }(\mathrm{cm}) \\
\text { Weight gain, } \mathrm{WG}(\mathrm{g})=\text { Final weight }(\mathrm{g})-\text { Initial weight }(\mathrm{g}) \\
\text { Specific growth rate, SGR }(\%)=\frac{\log \mathrm{w} 2-\log \mathrm{w} 1}{\mathrm{t}} \mathrm{X} 100
\end{gathered}
$$


Partial Replacement of Fishmeal with Marine Algae Turbinaria ornata and Gracilaria corticata for Sustainable Culture of the Freshwater Prawn Macrobrachium rosenbergii

where,

$\mathrm{w} 1 \&$ w2 represents initial and final weight $(\mathrm{g})$ respectively

' $\mathrm{t}$ ' is the total number of experimental days

$$
\text { Food conversion rate, FCR }(\mathrm{g})=\frac{\text { Total quantity of feed intake }(\mathrm{g})}{\text { Weight gain of the prawn }(\mathrm{g})}
$$

\subsection{Estimation of basic biochemical constituents}

The concentrations of basic biochemical constituents, such as total protein, carbohydrate, lipid, amino acid, moisture and ash in the muscle of prawns were determined. Concentration of total protein was estimated by the method of Lowry et al. (1951) using ethanolic precipitated sample. Concentration of total carbohydrate was estimated by the method of Roe (1955) using TCA extracted sample. Concentration of total lipid was extracted by following the method of Folch et al. (1957) and estimated by the method of Barnes and Blackstock (1973). Amino acids were extracted using sodium tungstate and $\mathrm{H}_{2} \mathrm{SO}_{4}$. The content of total amino acid was assayed by the method of Moore and Stein (1948). Ash and moisture were analyzed by the method of APHA (2005). All analysis was carried out in triplicates. For these parameters, tissues from five prawns were pooled together from each group to constitute a single observation and three such observations were made to fulfill the triplicate analysis.

\subsection{Analyses of profiles of proteins}

SDS-PAGE analysis was done in the muscle samples of prawns fed with control and $25 \%$ of fishmeal replaced with $T$. ornata, and $25 \%$ with $G$. corticata (the best concentration in each category) feeds. The muscle tissue sample was first defrosted in phosphate buffer $(137 \mathrm{mM} \mathrm{NaCl}, 2.7 \mathrm{mM} \mathrm{KCl}, 10$ $\mathrm{mM} \mathrm{Na} 2 \mathrm{HPO}_{4}$ and $\left.2 \mathrm{mM} \mathrm{KH}_{2} \mathrm{PO}_{4}, \mathrm{pH}-7.4\right)$, homogenized under ice cold condition and centrifuged at $1500 \mathrm{rpm}$ under $4{ }^{\circ} \mathrm{C}$ for $5 \mathrm{~min}$. The soluble protein content in supernatant was determined (Lowery et al., 1951). SDS-PAGE was performed on vertical slab gel with $4 \%$ stacking and $10 \%$ separating gels (Laemmli, 1970) along with protein markers of Medox-Biotech Pvt. Ltd., India ( $\beta$-galactosidase - 116 $\mathrm{kDa}$, bovine serum albumin - $66 \mathrm{kDa}$, ovalbumin - $45 \mathrm{kDa}$, carbonic anhydrase - $29 \mathrm{kDa}$, soybean trypsin inhibitor - $20 \mathrm{kDa}$ and lysozyme - $14 \mathrm{kDa}$ ). The polypeptides banding patterns between control and test prawns were compared by using the information on apparent molecular masses of bands and their intensities.

\subsection{Analyses of profiles of amino acids}

The profiles of amino acids were analyzed in the muscle samples of prawns fed with control and $25 \%$ of fishmeal replaced with $T$. ornata, and $25 \%$ with $G$. corticata (the best concentration in each category) feeds by using the High Performance Thin Layer Chromatographic (HPTLC) method (Hess and Sherma, 2004). The prawns were dried $\left(80{ }^{\circ} \mathrm{C}\right.$ for $\left.3 \mathrm{~h}\right)$, digested with $6 \mathrm{M}$ aqueous $\mathrm{HCL}$ and dried under vacuum. Samples ( $5 \mu 1$ of distilled $\mathrm{H}_{2} \mathrm{O}$ dissolved) were loaded on TLC plate pre-coated with Silica gel-60F254 ( $8 \mathrm{~mm}$ thick; $20 \mathrm{~cm} \times 15 \mathrm{~cm}$ ), processed by using CAMAG-LINOMAT 5 instrument and developed under Butane-Ammonia-Pyridine-Water (3.9:1:3.4:2.6) as mobile phase. The gel was sprayed with ninhydrin reagent prepared in propan-2-ol and dried. The developed gel was documented under CAMAG-11REPROSTAR 3 at $254 \mathrm{~nm}$ and $366 \mathrm{~nm}$ UV lights. Finally, the gel was scanned at $500 \mathrm{~nm}$ using CAMAG-TLC SCANNER 3. TLC for four groups of standard amino acids: lysine, asparagine, glutamine, glutamic acid and metheonine (group-I); proline, serine, cystine, tyrosine and tryptophan (group-II); histidine, arginine, aspartic acid, threonine and leucine (group-III); and glycine, alanine, valine, isoleucine and phenyl alanine (group-IV) were also performed simultaneously. The peak area of the sample was compared with standard amino acids and quantified.

\subsection{Analyses of profiles of fatty acids}

The profiles of fatty acids were analyzed in the muscle samples of prawns fed with control and $25 \%$ of fishmeal replaced with $T$. ornata, and $25 \%$ with G. corticata (the best concentration in each category) feeds by using the Gas Chromatographic (GC) method (Nichols et al., 1993). Fatty acid samples were obtained from lipid by saponification using $\mathrm{NaOH}$ dissolved in methanol- $\mathrm{H}_{2} \mathrm{O}$ mixture (hydrolysis with alkali). They were methylated into fatty acid methyl ester using methanol-HCl mixture. The fatty acid methyl ester was separated using hexane-anhydrous diethyl ether mixture. For the organic phase aqueous $\mathrm{NaOH}$ was used as base wash and the upper organic layer was separated. 2 
$\mu \mathrm{L}$ of sample was injected and analyzed using Chemito 8610 Gas Chromatography, with BPX70 capillary column and flame ionization detector. Nitrogen was used as carrier gas. Standard fatty acids were analyzed simultaneously. Based on the retention time of the standard fatty acids, each fatty acid in the unknown sample was identified. The peak areas of standard and unknown were compared and quantified.

\subsection{Activities of digestive enzymes}

The whole flesh except eye stalk and exoskeleton was homogenized in ice cold distilled water and centrifuged at $10,000 \mathrm{rpm}$ under $4^{\circ} \mathrm{C}$ for 20 minutes. The supernatant was used as crud enzyme source. The activity of protease was estimated by the method of Furne et al. (2005). One unit of enzyme activity represents the amount of enzyme required to liberate one $\mu \mathrm{g}$ of tyrosine min- 1 under assay conditions. The activity of amylase was assayed by following the method of Bernfeld (1955) in which the increase in reducing power of buffered starch solutions was measured. One unit of amylase activity was calculated as quantity (mg) of maltose liberated/g of protein/ $\mathrm{h}(\mathrm{mg} / \mathrm{g} / \mathrm{h})$. The activity of lipase was assayed by the method of Furne et al. (2005). One unit of lipase activity was defined as the amount of free fatty acid released from triacyl glycerol per unit time was estimated by the amount of $\mathrm{NaOH}$ required to maintain $\mathrm{pH}$ constant and represented as mille equivalents of alkali consumed.

\subsection{Statistical analysis}

Data between control versus experiments and between experiments were subjected to statistical analysis through one-way ANOVA and subsequent post hoc multiple comparison with DMRT by adopting the SPSS v16. All the details of statistical analyses were given in respective tables. The P values less than 0.05 were considered statistically (95\%) significant.

\section{RESUltS}

\subsection{Growth, nutritional indices and basic biochemical constituents}

The morphometric parameters (length and weight gains), nutritional indices (survival rate, specific growth rate and protein efficiency ratio) and concentrations of basic biochemical constituents (total protein, carbohydrate, lipid, amino acid and ash) were found to be significantly increased $(P<0.05)$ in $25 \%$ fishmeal replaced feeds fed prawns when compared with control, whereas the $50 \%$ fishmeal replacements showed significantly decreased growth, nutritional indices and contents of basic biochemical constituents when compared with control (Tables 4 and 5). The FCR was appeared reverse, that was lowest in 25\% fishmeal replaced feeds fed prawns and highest in 50\% fishmeal replaced feeds fed prawns when compared with control (Table 4). The lowest FCR recorded represents the best quality of feed. Among these two algae, G. corticata has produced better growth, nutritional indices and contents of basic biochemical constituents than that of T. ornata (Tables 4 and $5)$.

Table 4: Morphometric and nutritional indices of M. rosenbergii fed with diets prepared by partial replacement of fishmeal with $T$. ornata and $G$. corticata

\begin{tabular}{|l|c|c|c|c|c|}
\hline \multirow{2}{*}{ Parameter } & & \multicolumn{4}{|c|}{ Fishmeal replaced diets } \\
\cline { 2 - 6 } & & \multicolumn{2}{|c|}{ T. ornata } & \multicolumn{2}{c|}{ G. corticata } \\
\cline { 2 - 6 } & Control & $25 \%$ & $50 \%$ & $25 \%$ & $50 \%$ \\
\hline SR (\%) & $84.25 \pm 2.63^{\mathrm{c}}$ & $86.33 \pm 2.51^{\mathrm{b}}$ & $77.00 \pm 1.00^{\mathrm{e}}$ & $89.00 \pm 1.07^{\mathrm{a}}$ & $79.11 \pm 1.00^{\mathrm{d}}$ \\
\hline LG (cm) & $2.48 \pm 0.93^{\mathrm{bc}}$ & $2.50 \pm 0.90^{\mathrm{b}}$ & $1.76 \pm 0.13^{\mathrm{e}}$ & $2.74 \pm 0.17^{\mathrm{a}}$ & $1.85 \pm 0.17^{\mathrm{d}}$ \\
\hline WG (g) & $0.32 \pm 0.02^{\mathrm{c}}$ & $0.37 \pm 0.02^{\mathrm{b}}$ & $0.27 \pm 0.01^{\mathrm{de}}$ & $0.40 \pm 0.04^{\mathrm{a}}$ & $0.29 \pm 0.02^{\mathrm{d}}$ \\
\hline SGR (\%) & $0.63 \pm 0.06^{\mathrm{c}}$ & $0.68 \pm 0.05^{\mathrm{b}}$ & $0.56 \pm 0.04^{\mathrm{de}}$ & $0.74 \pm 0.05^{\mathrm{a}}$ & $0.57 \pm 0.04^{\mathrm{d}}$ \\
\hline FCR (\%) & $1.18 \pm 0.02^{\mathrm{c}}$ & $1.14 \pm 0.01^{\mathrm{cd}}$ & $1.35 \pm 0.02^{\mathrm{a}}$ & $1.12 \pm 0.03^{\mathrm{d}}$ & $1.36 \pm 0.03^{\text {ab }}$ \\
\hline PER (\%) & $1.92 \pm 0.03^{\mathrm{c}}$ & $1.98 \pm 0.02^{\mathrm{b}}$ & $1.73 \pm 0.01^{\mathrm{e}}$ & $2.04 \pm 0.02^{\mathrm{a}}$ & $1.76 \pm 0.02^{\mathrm{d}}$ \\
\hline
\end{tabular}

Each value is mean \pm standard deviation of three individual observations.

Mean values within the same row sharing different alphabetical letter superscripts are statistically significant at $P<0.05$ (one-way ANOVA and subsequent post hoc multiple comparison with DMRT.

$B I$, basal ingredients; SR, survival rate; LG, length gain; WG, weight gain; SGR, specific growth rate; FCR, food conversion ratio; PER, protein efficiency ratio. 
Partial Replacement of Fishmeal with Marine Algae Turbinaria ornata and Gracilaria corticata for Sustainable Culture of the Freshwater Prawn Macrobrachium rosenbergii

Table 5: Basic biochemical constituents of M. rosenbergii fed with diets prepared by partial replacement of fishmeal with T. ornata and G. corticata

\begin{tabular}{|l|c|c|c|c|c|}
\hline \multirow{2}{*}{$\begin{array}{l}\text { Parameters } \\
\text { (Total form) }\end{array}$} & \multirow{2}{*}{ Control $^{*}$} & \multicolumn{3}{|c|}{ Partially fishmeal replaced diets } \\
\cline { 3 - 6 } & & $\mathbf{2 5}(\mathbf{\%})$ & $\mathbf{5 0}(\boldsymbol{\%})$ & $\mathbf{2 5 \%}$ & $\mathbf{5 0 \%}$ \\
\cline { 3 - 6 } & $141.65 \pm 2.46^{\mathrm{c}}$ & $147.43 \pm 2.00^{\mathrm{b}}$ & $94.76 \pm 2.35^{\mathrm{de}}$ & $151.20 \pm 4.78^{\mathrm{a}}$ & $96.15 \pm 2.92^{\mathrm{d}}$ \\
\hline Protein (mg/g wet wt.) & $37.15 \pm 1.31^{\mathrm{c}}$ & $40.98 \pm 1.23^{\mathrm{b}}$ & $19.67 \pm 1.88^{\mathrm{de}}$ & $44.23 \pm 2.80^{\mathrm{a}}$ & $20.81 \pm 1.65^{\mathrm{d}}$ \\
\hline $\begin{array}{l}\text { Carbohydrate (mg/g } \\
\text { wet wt.) }\end{array}$ & & & & \\
\hline Lipid (mg/g wet wt.) & $36.75 \pm 0.85^{\mathrm{b}}$ & $39.68 \pm 0.99^{\mathrm{ab}}$ & $15.87 \pm 1.38^{\mathrm{e}}$ & $40.94 \pm 1.32^{\mathrm{a}}$ & $18.20 \pm 1.43^{\mathrm{d}}$ \\
\hline $\begin{array}{l}\text { Amino acid (mg/g wet } \\
\text { wt.) }\end{array}$ & $92.20 \pm 2.11^{\mathrm{b}}$ & $97.58 \pm 3.85^{\mathrm{ab}}$ & $81.22 \pm 2.57^{\mathrm{e}}$ & $99.61 \pm 2.43^{\mathrm{a}}$ & $83.68 \pm 2.31^{\mathrm{d}}$ \\
\hline Ash (\%) & & & & \\
\hline Moisture (\%) & $16.91 \pm 0.39^{\mathrm{bc}}$ & $18.32 \pm 0.40^{\mathrm{b}}$ & $12.00 \pm 1.00^{\mathrm{d}}$ & $21.09 \pm 0.78^{\mathrm{a}}$ & $14.26 \pm 1.43^{\mathrm{c}}$ \\
\hline
\end{tabular}

Each value is mean \pm standard deviation of three individual observations.

Mean values within the same row sharing different alphabetical letter superscripts are statistically significant at $P<0.05$ (one-way ANOVA and subsequent post hoc multiple comparison with DMRT.

\subsection{Profiles of proteins}

Polypeptide bands of molecular weight between 116-14 kDa were resolved in the muscle of prawns (Fig. 1). The Coomassie blue stained protein bands at some regions in $25 \%$ fishmeal replaced feeds fed prawns (71, 45, 29 and 20kDa of T. ornata incorporated feed, and 71, 66, 50, 45, 29, 26, 20, 15 and $14 \mathrm{kDa}$ of $G$. corticata incorporated feed) were found to be stained more intense than that of control. The resolved SDS-PAGE pattern revealed that among these two algae G. corticata showed better profile than that of $T$. ornata.

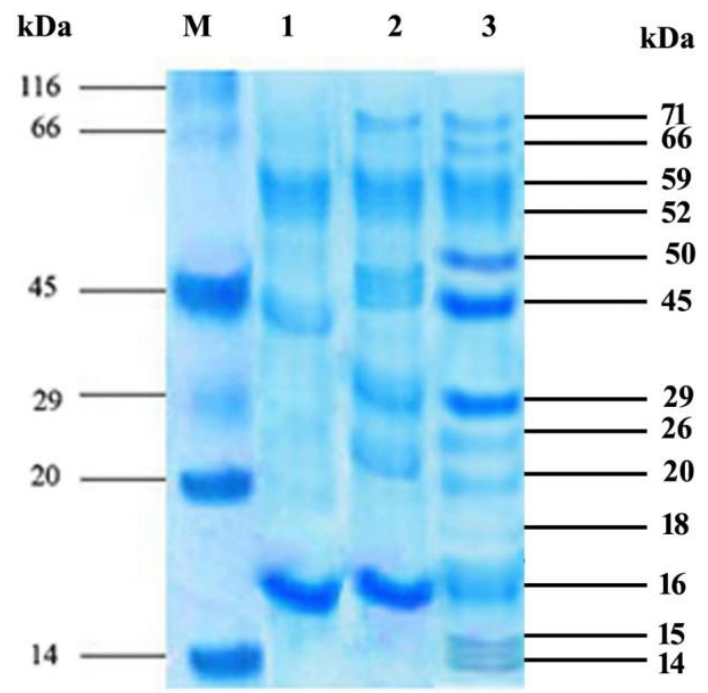

Fig. 1. SDS-PAGE pattern of muscle protein of $M$. rosenbergii PL fed with diets prepared by partial replacement of fishmeal with T. ornata and G. corticata.

Lane 1: Marker; Lane: 2; Control; Lane 3: $25 \%$ of fishmeal replaced diet with T. ornata. Lane 4: $25 \%$ of fishmeal replaced diet with $G$. corticata. $\mathrm{kDa}$, kilo Dalton; 116, $\beta$-galactosidase; 66, Bovine serum albumin; 45, ovalbumin; 29, carbonic anhydrase; 20 , soybean trypsin inhibitor; 14 , lysozyme.

\subsection{Profiles of amino acids}

There were eighteen amino acids detected in the muscle of prawns, of which eleven were essential amino acids (EAA), lysine, histidine, arginine, glycine, asparagine, threonine, valine, methionine, isoleucine, leucine and phenyl alanine, and seven were non-essential amino acids (NEAA), proline, glutamine, cystine, aspartic acid, alanine, glutamic acid and tyrosine (Table 6). Generally the content of all the EAA and NEAA were found to be significantly higher $(P<0.05)$ in $25 \%$ fishmeal replaced feeds fed prawns when compared with control (Table 6). Among these two marine algae G. corticata produced better results. 
Table 6: Profiles of amino acids ( $\mathrm{g} / 100 \mathrm{~g}$ dry wt.) in the muscle of M. rosenbergii fed with diets prepared by partial replacement of fishmeal with $T$. ornata and $G$. corticata

\begin{tabular}{|c|c|c|c|}
\hline Amino acids & Control & T. ornata $(25 \%)$ & G. corticata $(25 \%)$ \\
\hline Lysine $^{\mathrm{E}}$ & $3.26 \pm 0.16^{\mathrm{c}}$ & $3.96 \pm 0.02^{b}$ & $4.34 \pm 0.03^{\mathrm{a}}$ \\
\hline Histidine $^{\mathrm{E}}$ & $2.36 \pm 0.19^{c}$ & $2.96 \pm 0.02^{b}$ & $3.12 \pm 0.04^{\mathrm{a}}$ \\
\hline Arginine $^{\mathrm{E}}$ & $3.19 \pm 0.12^{c}$ & $4.33 \pm 0.03^{b}$ & $4.67 \pm 0.04^{\mathrm{a}}$ \\
\hline Glycine $^{\mathrm{E}}$ & $10.86 \pm 0.59^{c}$ & $12.13 \pm 0.02^{b}$ & $13.3 \pm 0.03^{\mathrm{a}}$ \\
\hline Asparagine $^{\mathrm{E}}$ & $7.11 \pm 0.03^{\mathrm{c}}$ & $9.51 \pm 0.03^{b}$ & $9.81 \pm 0.03^{\mathrm{a}}$ \\
\hline Threonine $^{\mathrm{E}}$ & $4.34 \pm 0.05^{\mathrm{c}}$ & $4.71 \pm 0.02^{b}$ & $5.02 \pm 0.04^{\mathrm{a}}$ \\
\hline Valine $^{\mathrm{E}}$ & $3.38 \pm 0.08^{\mathrm{c}}$ & $3.73 \pm 0.03^{b}$ & $3.89 \pm 0.03^{\mathrm{a}}$ \\
\hline Methionine $^{\mathrm{E}}$ & $2.89 \pm 0.15^{\mathrm{c}}$ & $2.94 \pm 0.04^{b}$ & $3.31 \pm 0.04^{\mathrm{a}}$ \\
\hline Isoleucine $^{\mathrm{E}}$ & $2.25 \pm 0.20^{\mathrm{c}}$ & $2.40 \pm 0.04^{b}$ & $2.83 \pm 0.03^{\mathrm{a}}$ \\
\hline Leucine $^{\mathrm{E}}$ & $4.10 \pm 0.24^{\mathrm{c}}$ & $4.75 \pm 0.01^{b}$ & $4.95 \pm 0.02^{\mathrm{a}}$ \\
\hline Phenyl alanine $^{\mathrm{E}}$ & $3.47 \pm 0.07^{\mathrm{c}}$ & $4.16 \pm 0.05^{b}$ & $4.59 \pm 0.05^{\mathrm{a}}$ \\
\hline Proline $^{\mathrm{NE}}$ & $6.54 \pm 0.55^{\mathrm{c}}$ & $7.32 \pm 0.02^{b}$ & $8.05 \pm 0.03^{\mathrm{a}}$ \\
\hline Glutamine $^{\mathrm{NE}}$ & $1.26 \pm 0.07^{\mathrm{c}}$ & $1.90 \pm 0.03^{b}$ & $2.46 \pm 0.04^{\mathrm{a}}$ \\
\hline Cystine $^{\mathrm{NE}}$ & $1.61 \pm 0.29^{c}$ & $2.16 \pm 0.04^{b}$ & $2.55 \pm 0.04^{\mathrm{a}}$ \\
\hline Aspartic acid $^{\mathrm{NE}}$ & $4.14 \pm 0.05^{\mathrm{c}}$ & $4.87 \pm 0.06^{b}$ & $5.12 \pm 0.05^{\mathrm{a}}$ \\
\hline Alanine $^{\mathrm{NE}}$ & $1.86 \pm 0.08^{\mathrm{c}}$ & $2.75 \pm 0.10^{\mathrm{b}}$ & $2.93 \pm 0.07^{\mathrm{a}}$ \\
\hline Glutamic acid $^{\mathrm{NE}}$ & $1.96 \pm 0.11^{\mathrm{c}}$ & $2.41 \pm 0.02^{b}$ & $2.78 \pm 0.12^{\mathrm{a}}$ \\
\hline Tyrosine $^{\mathrm{NE}}$ & $3.91 \pm 0.08^{c}$ & $4.21 \pm 0.06^{b}$ & $5.16 \pm 0.09^{\mathrm{a}}$ \\
\hline$\sum \mathrm{AA}$ & $68.80 \pm 2.69^{c}$ & $81.24 \pm 0.70^{\mathrm{b}}$ & $88.88 \pm 0.81^{\mathrm{a}}$ \\
\hline$\sum \mathrm{EAA}$ & $47.49 \pm 1.92^{\mathrm{c}}$ & $55.61 \pm 0.34^{b}$ & $59.83 \pm 0.38^{\mathrm{a}}$ \\
\hline$\sum$ NEAA & $21.30 \pm 0.71^{\mathrm{c}}$ & $25.62 \pm 0.35^{b}$ & $29.05 \pm 0.46^{\mathrm{a}}$ \\
\hline
\end{tabular}

Each value is mean \pm standard deviation of three individual observations.

Mean values within the same row sharing different alphabetical letter superscripts are statistically significant at $P<0.05$ (one-way ANOVA and subsequent post hoc multiple comparison with DMRT.

$A A$, amino acid; ${ }^{E}$, essential amino acids; ${ }^{N E}$, non essential amino acids

\subsection{Profiles of fatty acids}

There were ten fatty acids detected in the muscle of prawns (Table 7), of which five saturated (lauric acid, myristic acid, palmitic acid, stearic acid and arachidic acid), two mono saturated (palmitoleic acid and oleic acid) and three poly unsaturated fatty acids [linoleic acid (n-6), EPA (n-3) and DHA (n-3)]. Generally the total content of all these three groups of fatty acids were found to be significantly higher $(P<0.05)$ in $25 \%$ fishmeal replaced feeds fed prawns when compared with control (Table 7). The $\sum$ MUFA (palmitoleic acid and olecic acid) and $\sum$ PUFA (Linoleic acid, EPA and DHA) elevation was higher when compared with $\sum$ SFA in $25 \%$ fishmeal replaced feeds fed prawns when compared with control (Table 7). Among these two marine algae G. corticata produced better results.

Table 7: Profiles of fatty acids (\%) in the muscle of M. rosenbergii fed with diets prepared by partial replacement of fishmeal with $T$. ornata and $G$. corticata

\begin{tabular}{|l|l|c|c|c|}
\hline \multicolumn{2}{|l|}{ Fatty acids } & Control & T. ornata (25\%) & G. corticata (25\%) \\
\hline \multirow{3}{*}{ SFA } & Lauric acid (C12:0) & $0.55 \pm 0.03^{\mathrm{c}}$ & $1.20 \pm 0.06^{\mathrm{b}}$ & $1.67 \pm 0.03^{\mathrm{a}}$ \\
\cline { 2 - 5 } & Myristic acid (C14:0) & $0.40 \pm 0.02^{\mathrm{c}}$ & $1.18 \pm 0.02^{\mathrm{b}}$ & $1.47 \pm 0.02^{\mathrm{a}}$ \\
\cline { 2 - 5 } & Palmitic acid (C16:0) & $13.13 \pm 0.10^{\mathrm{c}}$ & $15.30 \pm 0.16^{\mathrm{b}}$ & $16.94 \pm 0.95^{\mathrm{a}}$ \\
\cline { 2 - 5 } & Stearic acid (C18:0) & $8.25 \pm 0.11^{\mathrm{c}}$ & $9.66 \pm 0.12^{\mathrm{b}}$ & $9.72 \pm 0.53^{\mathrm{a}}$ \\
\cline { 2 - 5 } & Arachidic acid (C20:0) & $0.72 \pm 0.05^{\mathrm{c}}$ & $1.25 \pm 0.05^{\mathrm{b}}$ & $2.09 \pm 0.57^{\mathrm{a}}$ \\
\hline \multirow{3}{*}{ MUFA } & Palmitoleic acid (C16:1) & $9.18 \pm 0.05^{\mathrm{c}}$ & $11.52 \pm 0.10^{\mathrm{b}}$ & $11.73 \pm 0.26^{\mathrm{a}}$ \\
\cline { 2 - 5 } & Olecic acid (C18:1) & $7.54 \pm 0.03^{\mathrm{c}}$ & $10.24 \pm 0.25^{\mathrm{b}}$ & $11.71 \pm 0.08^{\mathrm{a}}$ \\
\hline \multirow{3}{*}{ PUFA } & Linoleic acid (C18:2 n-6) & $8.64 \pm 0.09^{\mathrm{c}}$ & $11.08 \pm 0.22^{\mathrm{b}}$ & $12.92 \pm 0.05^{\mathrm{a}}$ \\
\cline { 2 - 5 } & EPA (C20:5 n-3) & $1.15 \pm 0.07^{\mathrm{c}}$ & $2.19 \pm 0.15^{\mathrm{b}}$ & $3.20 \pm 0.09^{\mathrm{a}}$ \\
\cline { 2 - 5 } & DHA (C22:6 n-3) & $1.25 \pm 0.05^{\mathrm{c}}$ & $3.25 \pm 0.05^{\mathrm{b}}$ & $4.44 \pm 0.03^{\mathrm{a}}$ \\
\hline ZFA & $50.84 \pm 0.03^{\mathrm{c}}$ & $66.90 \pm 0.07^{\mathrm{b}}$ & $75.92 \pm 0.31^{\mathrm{a}}$ \\
\hline ZSFA & $23.06 \pm 0.04^{\mathrm{c}}$ & $28.60 \pm 0.05^{\mathrm{b}}$ & $31.90 \pm 0.39^{\mathrm{a}}$ \\
\hline$\sum$ MUFA & $16.73 \pm 0.01^{\mathrm{c}}$ & $21.76 \pm 0.03^{\mathrm{b}}$ & $23.44 \pm 0.12^{\mathrm{a}}$ \\
\hline$\sum$ PUFA & $11.04 \pm 0.02^{\mathrm{c}}$ & $16.52 \pm 0.08^{\mathrm{b}}$ & $20.57 \pm 0.02^{\mathrm{a}}$ \\
\hline n-3 & $2.40 \pm 0.01^{\mathrm{c}}$ & $5.44 \pm 0.07^{\mathrm{b}}$ & $7.65 \pm 0.03^{\mathrm{a}}$ \\
\hline n-6 & $8.64 \pm 0.09^{\mathrm{c}}$ & $11.08 \pm 0.22^{\mathrm{b}}$ & $12.92 \pm 0.09^{\mathrm{a}}$ \\
\hline
\end{tabular}


Partial Replacement of Fishmeal with Marine Algae Turbinaria ornata and Gracilaria corticata for Sustainable Culture of the Freshwater Prawn Macrobrachium rosenbergii

Each value is mean \pm standard deviation of three individual observations.

Mean values within the same row sharing different alphabetical letter superscripts are statistically significant at $P<0.05$ (one-way ANOVA and subsequent post hoc multiple comparison with DMRT.

FA, fatty acids; SFA, saturated fatty acids; MUFA, mono unsaturated fatty acids; PUFA, poly unsaturated fatty acids.

\subsection{Activities of digestive enzymes}

Activities of digestive enzymes, protease, amylase and lipase were significantly $(P<0.05)$ elevated in $25 \%$ fishmeal replaced feeds fed prawns when compared with control. Among these two marine algae G. corticata produced more elevation in activities of these enzymes (Table 8).

Table 8: Activity of digestive enzymes of $M$. rosenbergii fed with diets prepared by partial replacement of fishmeal with T. ornata and G. corticata

\begin{tabular}{|l|c|c|c|}
\hline \multirow{2}{*}{ Parameters } & \multirow{2}{*}{ Control } & \multicolumn{2}{|c|}{ Partially fishmeal replacement diets } \\
\cline { 3 - 4 } & & T. ornata $(\mathbf{2 5 \% )}$ & G. corticata (25\%) \\
\hline Protease (U/mg protein) & $1.53 \pm 0.49^{\mathrm{c}}$ & $1.61 \pm 0.55^{\mathrm{b}}$ & $1.73 \pm 0.52^{\mathrm{a}}$ \\
\hline Amylase (U/mg protein) & $0.90 \pm 0.23^{\mathrm{bc}}$ & $0.93 \pm 0.21^{\mathrm{b}}$ & $1.13 \pm 0.30^{\mathrm{a}}$ \\
\hline Lipase $\left(\times 10^{2} \mathrm{U} / \mathrm{mg}\right.$ protein) & $0.35 \pm 0.05^{\mathrm{c}}$ & $0.43 \pm 0.07^{\mathrm{b}}$ & $0.52 \pm 0.04^{\mathrm{a}}$ \\
\hline
\end{tabular}

Each value is mean \pm standard deviation of three individual observations.

Mean values within the same row sharing different alphabetical letter superscripts are statistically significant at $P<0.05$ (one-way ANOVA and subsequent post hoc multiple comparison with DMRT.

\section{DisCuSSION}

In the present study, the result recorded clearly indicated the fact that $25 \%$ fishmeal replaced feeds with $T$. ornata and $G$. corticata produced better survival, growth, protein, amino acids (EAA and NEAA), fatty acids (SFA, MUFA and PUFA), and digestive enzymes (protease, amylase and lipase) activities when compared with control by accumulation of nutrients due to active principles of these algae. Body biochemical composition is a good indicator for physiological condition and easy to assess the cultivable organisms. Protein is one of the major components of prawn feeds as larvae and juveniles have greater protein prerequisite than adults for growth and metabolism. Dietary protein supplies amino acids required to build body tissues essential for growth and production of hormones, antibodies, enzymes etc., (Gimenez et al., 2009). Generally, crustacean muscles contain high concentration of free amino acids, such as arginine, glycine, proline, glutamine, alanine, lysine, tryptophan, valine and histidine, which are involved in energy metabolism and protein synthesis (Bhavan et al., 2010). The free amino acids are plays an important role in osmoregulation, neurotransmitter, protein synthesis etc., (Fang et al., 1992; Mullen and Martin, 1992; Wilson, 2002). One of the major requirements of prawn culture is the transformation of dietary protein into tissue protein, which is essential for normal function, growth and maintenance. Dietary lipids are vital in providing essential fatty acids as they are yield energy, maintain the structural integrity of biological membranes, functions as precursors for important steroids, phospholipids, act as carriers of fat soluble vitamin $\mathrm{A}, \mathrm{D}, \mathrm{E}$ and $\mathrm{K}$, and essential for growth, moulting and reproduction including egg hatchability and larval survival (Corbin et al., 1983; Kanazawa et al., 1985; Xu et al., 1994; Yepiz-Plascencia et al., 2000; Vasagam et al., 2005). Carbohydrates are the most economical and inexpensive source of energy. It together with proteins and lipids form dietary source of energy, and are important in synthesis of chitin, steroid, fatty acids and glycogen (Mukhopadhyay et al., 2003). Therefore, 25\% fishmeal replaced with $T$. ornata and $G$. corticata have more influences on growth and nutritional profiles of $M$. rosenbergii due to the enhanced activities of digestive enzymes, as they have been reported to regulate the growth and moult cycle directly or indirectly (Lovett and Felder, 1990; Sun et al., 2011). Actually, crustaceans can able to digest a variety of complex food materials as they contain high concentration of protein, carbohydrate and lipid digesting enzymes, such as pepsin, trypsin, chymotrypsin, carboxypeptidases-A and B, leucine, aminopeptidase, amylase, collagenase, esterase and lipase (Gamboa-Delgado et al., 2003; Debnath et al., 2007).

The maximum survival, growth and nutritional indices have been reported in prawns fed with $50 \%$ partial replacement of the fishmeal with Chlorella vulgaris (Radhakrishnan et al., 2015). The growth- 
promoting effect of Chlorella has also been reported in the fish Gibel carps, Carassius auratus gibelio (Xu et al., 2014). The partial replacement of fish meal by microalgae Spirulina platensis, Hypnea cervicornis and Cryptonemia crenulata have also been reported in juvenile Pacific white shrimp, Litopenaeus vannamei with significant increase of growth (Hanel et al., 2007). The marine alga, Enteromorpha sp. supplementation has also been reported for better growth performance and FCR in Penaeus monodon, Penaeus indicus, Papeneopsis stylirostris, L. vennamei and M. rosenbergii (Bray et al., 1990). Sunitha and Rao (2003) have reported better weight gain in Tilipia mossambica when fed with blue green algae (Chlorella, Anabaena, Oscillatoria, Nostoc). Effects of Gracilaria bursapastoris, Ulva rigida and Gracilaria cornea have been evaluated in the juveniles of the European seabass, Dicentrarchus labrax (Valente et al., 2006).

\section{Conclusion}

Finally, this study recommends $25 \%$ of fishmeal can be replaced by T. ornata and G. corticata raw powders as these macro algae are low cost materials and available aplenty. They can be utilized for sustainable development of $M$. rosenbergii culture.

\section{ACKNOWLEDGEMENTS}

The authors are gratefully acknowledged Dr. M. Palanisamy, Scientist ' $C$ ', Southern Regional Centre, Botanical Survey of India (BSI), Coimbatore, India, for authentication of the marine algae, Turbinaria ornata and Gracilaria corticata. Animal Feed Analytical and Quality Assurance Laboratory (AFAQAL), Veterinary College and Research Institute, TANUVAS, Namakkal, Tamil Nadu, India, is acknowledged for proving the outsourcing services of analyses of the proximate compositions of feeds formulated.

\section{REFERENCES}

AOAC. (1995). Official methods of analysis of AOAC international. 2 vol. 16th Edn. Association of Analytical Communities. (Arlington, VA, USA).

APHA. (2005). Standard Methods for the Examination of Water and Wastewater, 20th ed. (American Public Health Association, New York).

Barnes, H., and Blackstock, J. (1973). Estimation of lipids in marine animals and tissues. Detail investigation of the sulpho-phosphovanillin method for total lipids. J. Exp. Mar. Bio. Eco., 12, 103-118.

Bernfeld, P. (1955). Amylases, in: Colowick, S.P., Kaplan, N.O. (Eds.), Methods in Enzymology. Academic Press, New York, pp. 149-158.

Bhavan, P.S., Ruby, S.A, Poongodi, R., Seenivasan, C., and Radhakrishnan, S. (2010). Efficacy of cereals and pulses as feeds for the post-larvae of the freshwater prawn Macrobrachium rosenbergii. J. Ecobiotech., 2(5):09-19.

Bray, W.A., Lawrence, A.L., and Lester, L.J. (1990). Reproduction of eyestalk-ablated Penaeus stylirostris fed various levels of total dietary lipids. J. World. Aquacult. Soc., 21:41-52.

Corbin, J.S., Fujimoto, M.M., and Iwai Jr, T.Y. (1983). Feeding practices and nutritional considerations for Macrobrachium rosenbergii culture in Hawaii. In: McVey, J.P., Moore, J.R. (Eds.), CRC Handbook of Mariculture. Crustacean Aquaculture. CRC Press, Boca Raton, pp. $391-442$.

D'Abramo, L.R., and Sheen, S.S. (1994). Nutritional requirements, feed formulation and feeding practices for intensive culture of the freshwater prawn Macrobrachium rosenbergii. Rev. Fish. Sci., 2:1-21.

Debnath, D., Pal, A.K., Sahu, N.P., Yengkokpam, S., Baruah, K., Choudhury, D., and Venkateshwarlu, G. (2007). Digestive enzymes and metabolic profile of Labeo rohita fingerlings fed diets with different crude protein levels. Comp. Biochem. Physiol., 146 (B):107-114.

Fang, L.S., Tang, C.K., Lee, D.L., and Chen, I.M. (1992). Free amino acid composition in muscle and hemolymph of the prawn Penaeus monodon in different salinities. Nip. Suis. Gak.. 58:10951102 .

Folch, J., Lees, M., and Bloane-Stanley, G.H. (1957). A simple method for the isolation and purification of total lipids from animal tissues. J. Bio. Chem., 266:497-509. 
Partial Replacement of Fishmeal with Marine Algae Turbinaria ornata and Gracilaria corticata for Sustainable Culture of the Freshwater Prawn Macrobrachium rosenbergii

Furne, M., Hidalgo, M.C, Lopez, A., Garcia-Gallego, M., Morales, A.E., Domezain, A., Domezain, J., and Sanz, A. (2005). Digestive enzyme activities in Adriatic sturgeon Acipenser naccarii and rainbow trout Oncorhynchus mykiss. A comparative study. Aquaculture, 250:391-398.

Gamboa-Delgado, J., Molina-Poveda, C., and Cahu, C. (2003). Digestive enzyme activity and food ingesta in juvenile shrimp Litopenaeus vannamei (Boone, 1931) as a function of body weight. Aquacult. Res., 34:1403-1411.

Gimenez, A.V.F., Dia, A.C., Velurtas, S.M., and Fenucci, J.L. (2009). Partial substitution of fishmeal by meat and bone meal, soybean meal, and squid concentrate in feeds for the prawn, Artemesia longinaris: Effect on digestive proteinases. Isr. J. Aquacult. Bamidgeh., 61:48-56.

Goda, A.M.A.S., Wafa, M.A., El-Haroun, E.R., and Chowdhary, M.A.K. (2007). Growth performance and feed utilization of Nile tilapia Oreochromis niloticus (Linnaeus, 1758) fingerlings and tilapia galilae, Sarotherodon galilaeus (Linnaeus, 1758) fingerlings fed plant protein-based diets. Aquacult. Res., 38:827-837.

Hanel H, Broekman D., De Graaf, S., and Schnack, D. (2007). Partial replacement of fishmeal by lyophilized powder of the microalgae Spirulina platensis in pacific white shrimp diets. Mar. Biol. J., 1:1-5.

Hardy, R.W. (2001). Urban legends and fish nutrition, Part 2. Aquacult. Magaz., 27(1):57-60.

Hernandez, C., Olvera-Novoa, M.A., Hardy, R.W., Hermosillo, A., Reyos, C., and Gonzalez, B. (2010). Complete replacement of fish meal by porcine and poultry byproduct meals in practical diets for fingerling Nile tilapia Oreochromis niloticus: Digestibility and growth performance. Aquacul. Nutr., 16:44-53.

Hess, B., and Sherma, J. (2004). Quantification of arginine in dietary supplement tablets and capsules by silica gel high-performance thin-layer chromatography with visible mode densitometry. Acta Chromatogr., 14:60-69.

Indegaard, M., and Minsaas, J. (1991). Animal and Human Nutrition. In: Guiry, M. D. and Blunden G. (Eds.), Seaweed Resources in Europe, Uses and Potential. John Wiley \& Sons. 21-64.

Kaliaperumal, N., Kalimuthu, S., and Ramalingam, J.R. (1995). Economically Important Seaweeds, in: Devaraj, M. (Ed.), Special publication number 62, Central Marine Fisheries Research Institute, Indian Council of Agricultural Research (ICAR), Cochin, India. pp. 1-35.

Kanazawa, A., Teshima, S., and Sakamoto, M. (1985). Effects of dietary lipids, fatty acids, and phospholipids on growth and survival of prawn (Penaeus japonicus) larvae. Aquaculture, 50:3949.

Kaushik, S.J., Cravedi, J.P., Lallas, J.P., Sumpter, J., Fauconneau, B., and Laroche M. (1995). Partial or total replacement of fish meal by soybean protein on growth, protein utilization, potential estrogenic or antigenic effects, cholesterolemia and flesh quality in rainbow trout, Oncorhynchus mykiss. Aquaculture, 133:257-274.

Laemmli, U.K. (1970). Cleavage of structural proteins during the assembly of the head bacteriophage T4. Nature, 227:680-685.

Langer, S., Bakhtiyar, Y., and Lakhnotra, R. (2011). Replacement of fishmeal with locally available ingredients in diet composition of Macrobrachium dayanum. Afri. J. Agri. Res., 6(5):1080-1084.

Lovett, D.L., and Felder, D.L. (1990). Ontogenic change in digestive enzyme activityof larval and postlarval white shrimp Penaeus setiferus (Crustacea, Decapoda, Penaeidae). Biol. Bull., 178:144-159.

Lowry, O.H., Rosenbrough, W.J., Fair, A.L., and Randall, R.J. (1951). Protein measurement with the Folin phenol reagent. J. Bio. Chem., 193:265-275.

Manilal, A., Sujith, S., Kiran, G.S., Selvin, J., Shakir, C., Gandhimathi, R., and Lipton, A.P. (2009). Antimicrobial potential and seasonality of red algae collected from the southwest coast of India tested against shrimp, human and phytopathogens, Ann. Microbiol., 59(2):207-219.

Manivannan, K., Karthikai Devi, G., Anantharaman, P., and Balasubramanian, T. (2011). Antimicrobial potential of selected brown seaweeds from Vedalai coastal waters, Gulf of Mannar. Asi. Paci. J. Trop. Bio., 1(2):114-120.

Martin, J.W., and Davis, G.E. (2001). An updated classification of the recent Crustacea. Natural History Museum, Los Angeles County, Science Series 39. 
Mitra, G., Chattopadhyay, D.N., and Mukhopadhyay, P.K. (2005). Nutrition and feeding in freshwater prawn (Macrobrachium rosenbergii) farming. Aqua feeds: Formulation and Beyond 2:17-19.

Moore, S., and Stein, W.H. (1948). Photometric ninhydrin method for use in the chromatography of amino acid. J. Bio. Chem., 176:367-388.

Mukhopadhyay, P.K, Rangacharyulu, P.V., Mitra, G., and Jana, B.B. (2003). Applied nutrition in freshwater prawn, Macrobrachium rosenbergii culture. J. Appl. Aquacult., 13:317-340.

Mullen, B.J., and Martin, R.J. (1992). The effect of dietary fat on diet selection may involve central serotonin. Amer. J. Physio. Regul. Integ. Comp. Phys., 263:559-563

Murugaiyan, K., Narasimman, S., and Anatharaman, P. (2012). Proximate composition of marine macro algae from Seeniappa Dharka, Gulf of Mannar region, Tamil Nadu. Int. J. Res. Mar. Sci., $1(1): 1-3$.

New, M.B., and Nair, C.M. (2012). Global scale of freshwater prawn forming. Aquacult. Res., 43:960-969.

Nichols, D.S., Nichols, P.D., and Mc Meekin, T.A. (1993). Polyunsaturated fatty acids in Antarctic bacteria. Antar. Sci., 5:149-160.

Parthiban, C., Saranya, C., Girija, K., Hemalatha, A., Suresh, M., and Anantharaman, P. (2013). Biochemical composition of some selected seaweeds from Tuticorin coast. Adv. Appl. Sci. Res., 4(3):362-366.

Radhakrishnan, S., Bhavan, P.S., Seenivasan, C., and Muralisankar, T. (2015). Effect of dietary replacement of fishmeal with Chlorella vulgaris on growth performance, energy utilization and digestive enzymes in Macrobrachium rosenbergii post larvae. Int. J. Fish. Aqua., 7(5):62-70.

Roe, J.H. (1955). The determination of sugar and blood and spinal fluid with anthrone reagent. J. Bio. Chem., 212:335-43.

Rosenberry, B. (2005). World shrimp farming 2005. Shrimps news international. pp. 276.

Salvador, N., Gomez-Garreta, A., Lavelli, L., and Ribera, L. (2007). Antimicrobial activity of Iberian macroalgae. Sci. Mar., 71:101-113.

Sun, S.M., Chen, M., Chen, L.Q., Jiang, H.B., Li, E.C., 2011. Optimal dietary copper, zinc requirements for juvenile Chinese mitten crab, Eriocheir sinensis. Isr. J. Aquacult. Bamid., 63:580-587.

Sunitha, M., and Rao, D.G. (2003). Bioconversion of mango processing waste to fish feed by microalgae isolated from fruit processing industrial effluents. J. Sci. Indus. Res., 62:344-347.

Swamy, D.N. 1995. CIBA, Madras "Training Manual, Short-Term Cource in Biotechnological Approaches in Prawns and Fish Nutrition and Feed Technology", 15th February to 7th March, pp. 82-88.

Tekinay, A.A., and Davies, S.J. (2001). Dietary carbohydrate level influencing feed intake, nutrient utilization and plasma glucose concentration in the rainbow trout, Oncorhynchus mykiss. Turk. J. Vet. Ani. Sci., 25:657-666.

Valente, L.M.P., Gouveia, A., Rema, P., Matos, J., Gomes, E.F., Pinto, I.S., 2006. Evaluation of three seaweeds Gracilaria bursa-pastoris, Ulva rigida and Gracilaria cornea as dietary ingredients in European sea bass Dicentrarchus labrax juveniles. Aquaculture, 252:85-91.

Vasagam, K.K.P., Ramesh, S., and Balasubramanian, T. (2005). Dietary value of different vegetable oil in black tiger shrimp Penaeus monodon in the presence and absence of soy lecithin supplementation: effect on growth, nutrient digestibility and body composition. Aquaculture, 250:317-327.

Wilson, R.P. (2002). Amino acids and Protein. In Halver, J. E., and Hardy, R. W., (Eds.), Fish Nutrition, Academic Press, San Diego. CA, USA. pp. 143-179.

Xu, W., Gao, Z., Qi, Z., Qiu, M., Peng, J.Q., and Shao, R., 2014. Effect of dietary Chlorella on the growth performance and physiological parameters of gibel carp, Carassius auratus gibelio. Turk. J. Fish. Aquat. Sci., 14:53-57.

Xu, X.L., Ji, W.J., Castell, J.D., and O'Dor, R.K. (1994). Influence of dietary lipid sources on fecundity, egg hatchability and fatty acid composition of Chinese prawn (Penaeus chinensis) brood stock. Aquaculture, 119:359-370. 
Partial Replacement of Fishmeal with Marine Algae Turbinaria ornata and Gracilaria corticata for Sustainable Culture of the Freshwater Prawn Macrobrachium rosenbergii

Yang, Y.F., Fei, X.G., Song, J.M., Hu, H.Y., Wang, G.C., and Chung, I.K., 2006. Growth of Gracilaria lemaneiformis under different cultivation conditions and its effects on nutrient removal in Chinese coastal waters. Aquaculture, 254:248-255.

Yepiz-Plascencia, G., Vargas-Albores, F., and Higuera-Ciapara, I. (2000). Penaeid shrimp hemolymph lipoproteins. Aquaculture, 191:177-189. 